\title{
Food Production through Traditional Agriculture: an Urgent Need to Improve Soil Health by Sustaining Soil Microbial Diversity
}

\author{
Sanoj Kumar Patel, Archana Singh and Gopal Shankar Singh* \\ Institute of Environment \& Sustainable Development, Banaras Hindu University \\ Varanasi-221005, Uttar Pradesh, India \\ *Corresponding author
}

\section{Keywords}

Traditional agriculture,

Microbial diversity, Soil health, Crop diversity, Food security

\section{Article Info}

Accepted:

04 December 2018

Available Online:

10 January 2019

\section{A B S T R A C T}

Sustainability of soil system and crop productivity is the greatest challenges in the twentyfirst century. The growing population pressurized modern agricultural practices to enhance food production. Green-revolution derived modern agriculture is characterized by the use of high-yielding crop varieties, inappropriate application of synthetic fertilizers and intensive water and energy resources utilization. Although, modern agriculture increased the food production several folds, but at cost of huge environmental degradation such as climate change, environmental pollution, degradation of soil health and biodiversity (soil microbial biodiversity). Soil microbial diversity is an important indicator of soil health that sustain various biogeochemical cycles in the soil system. The traditional agriculture has the novel capability of the environment and soil health management including soil microbial diversity. It enhances the spatial distribution of microbial diversity and its metabolic versatility which is vital for soil health. The tradition of India including various types of traditional agriculture practices because of its diverse weather. Mixed cropping, compost based cropping, agroforestry and livestock integrated agriculture practices are common in India since ages. The policy makers and scientific society are reevaluating the potential of these natural agriculture practices which fully depend on the biological and energy efficient inputs. The overall objective of this article is to highlight the potentials of traditional agriculture in respect to natural resource conservation including soil microbial system.

\section{Introduction}

Traditional agriculture is the holistic perspective for the conservation of the soil health sustainability. It is a dynamic tool for the conservation of natural resources such as water and agro-ecosystem from landscape to family farms. These farming system are based on the ecological principle and the ecofriendly indigenous knowledge (Chhetry and
Belbahri, 2009). Traditional agriculture is organic in nature and involves the environment and existing natural resources for organic input. These are the ancient crop production system and practiced from hundreds of years to fulfill the food requirement. The large proportion of the rural community survived on the family farm system, which also contributes greater than half of the global food production (FAO, 
2011; IFAD, 2012; Dogliotti et al., 2014). The traditional agricultural practices can be defined as "a set of knowledge, practice and trust which develop by their adaptive nature and pass to the new one by cultural transmission and explain the relationship between living being with their environment" (Berkes et al., 2000). The important feature of traditional farming is the adaptation to the local climate with spatial and sequential diversity which frequently obtained by double cropping, mixed cropping, use of local varieties with host-pathogen interaction, extensive use of local resources and tools for cultivation. The uniqueness of these practices are ecologically benign, publicly accepted, environmentally sound and economically feasible (Wezel et al., 2011; Morelli, 2018). Such as mixed cropping, which is effective to minimize the risk of pest and mono-crop failure (Singh and Singh, 2017). Whereas, agroforestry and shifting cultivation promote nutrient cycle conservation ecologically and mainly practiced by the tribal of North-east India and state of Orissa and Maharashtra (Sinha, 1997; Murthy et al., 2013).

The soil is an extremely heterogeneous and complicated micro-habitat. It considers one of the most complex and diversify ecosystems of the earth (Camenzind et al., 2018), which is reflected in the spatial distribution and contains a vast diversity of microbes and their secreted metabolic versatility (Buckley and Schmidt, 2003). The microbial diversity of soil enhancing the soil quality, by the cycling of nutrient element and regulate carbon sequestration and emission. It plays a critical role in dynamics of soil organic matter, which shape the soil physical and biological properties and the underground water regime (Söderström et al., 2014). The activity of microscopic diversity of soil enhanced the efficiency of nutrient uptake by the vegetation and endorses plant health by massive production. The rhizospheric soil mainly comprises bacteria, protozoans, algae and fungi diversity, which actively participates in the cycling of every type of nutrient element (Schloter et al., 2018; Kaurin et al., 2018). The plant growth promoting rhizobacteria (PGPR), cyanobacteria and mycorrhiza have the dual advantage, one way they promote the growth of the crop, on the other hand, they also deliver immunity against the pathogen attack (Glick, 1995; Rasmann, 2017). These microbes directly contact with root surface or by root nodules formation. The root nodules boosted the growth of the plant by available the mineral nutrient and enhanced the phytohormone production and suppression of pest attack (Haas and Defago, 2005). Various PGPR strains have been used positively for crop inoculations, including members of Azospirillum, Azotobacter, Bacillus, Enterobacter, Pseudomonas, Serratia and Xanthomonas (Lucy et al., 2004; Kumar et al., 2017).

Traditional agriculture is the low-input and natural farming system. It basically depends on the natural resources and local tools for input. This technique maintains the soil health with soil microbial diversity for future food production and food security. The soil nutrient and water are essential component of soil, because roots of the plant comprise the essential parts for nutrient and water uptake. The plant and microbial diversity of the topsoil mainly depend on nutrients and the photo assimilated plant roots. Additionally, plants available the soil organic matter (SOM) by decomposition of leaf litters and root exudates. For the supply and recycling of nutrient in rhizosphere, symbiotic association of different microbial community and saprotrophic fungi are necessary. These are the reasons for the microbial biodiversity, microbial biomass, enzyme activity and respiration should be considered as the excellent indicator of healthy soil (Paz-Ferreiro et al., 2016). Change in the 
microbial biodiversity in the soil system is an early alarm of soil amelioration.

The green revolution in India has brought tremendous growth in agriculture production by the use of the high yielding varieties, expansion of irrigation technology, promotion of synthetic fertilizer and pesticide. This revolution increased the production of the crop by enhanced cropping intensity of mono-crops which made country self-dependent in food production. The percentage of population below the poverty line in rural region of India reduces from $53 \%$ in 1978 to $27 \%$ in 1999 (Mohan, 2006). But it has two sides, one way it increases the production, on the other hand, it harms the agro-ecosystem adversely by extensive use of chemical fertilizer and pesticides (Srivastava, et al., 2016). The chemical based agriculture accumulated a large amount of nitrate in the water with high level of heavy metal contamination. At the same time, to complete the high input requirement of the modern agriculture there has been an increase in by factor 56, 22 and 34 times of tractors, pump sets and use of fertilizer (Bhalla and Singh, 2009). The modern agricultural technologies and high chemical input disturbed and contaminated natural cropping system. That leads to disappearance of soil microbial diversity and disrupt the agro-ecosystem. Agricultural intensification is evident as one of the major threats to global biodiversity (CBD, 2010; Abberton et al., 2016). Visualizing the degradation rate of the agricultural ecosystem is the urgent need to reduce the overexploitation of natural resources for sustainable use of these natural resources, and hand over of resources to the future generation. The main focus of this article is to highlight the potential of traditional agricultural practices towards conservation of the soil microbial system and sustainability of the agriculture system. This study also shows the environmental feasibility of natural system and awareness among the people about the importance of these traditional practices.

\section{Ecological extent of traditional agriculture practices}

The traditional farming has a distinctive feature in respect of microbial diversity as well as sustainable agriculture production (Fig. 1). It encompassed the great dissimilarity between natural and semi-natural plantation (Plieninger et al., 2006). The sustainability of traditional agriculture connotes towards the quality of agriculture product with the rhizospheric soil condition. The traditional agriculture practices performed in many forms, but its fundamental feature is to expel the use of the industrial tactic and promote maximum use of local tools with natural and local resources. These practices are effective for more agronomic production as well as the soil conservation in local climatic condition. It increases soil organic carbon with the recovery of soil structure, mitigates greenhouse emission by leguminous cultivation and reducing the oxidation of assimilated soil carbon (Balota et al., 2004; Chivenge et al., 2007; Friedrich et al., 2009; Lal, 2009; Chenu et al., 2018). Traditional agriculture increasing the nutrient and microbial diversity of soil with high soil moisture. This soil moisture reduces erosion of cultivated soil. The activity of soil enzyme increases transformation of unobtainable nutrient to active and available form (Yadav et al., 2013; Menezes-Blackburn et al., 2016). The organic compost mainly comprises bacteria and fungi with fresh humic substances that are not only rich in microbial biomass but also stimulates the activity of microbes (Bitew and Alemayehu, 2017). It also helps in diminishing attack of nematodes and moderating the influence of pesticide by sorption (Yadav et al., 2013). The number of earthworm population considerable as important in organic farming in context to 
modern cultivation. The earthworm has dual ability to restore soil fertility with significant increases in crop production.

\section{Important traditional agricultural practices (TAP) of India}

The history of Indian agriculture rich in traditional farming. It covers various types of traditional agriculture practices, which work as the natural, low-input and energy efficient system. This system comprises numerous biodiverse, climate resilience, energetically proficient and socially accepted practices. In these practices, farmers diversify the farm system by age-old practices of agroforestry, mixed or intercropping, cover crops and livestock-based farming (Anbalagan et al., 2016; Rao et al., 2018; Ram et al., 2017). The diverse weather of the country also responsible to create various types of traditional agriculture practices. After the modernization and mechanization of agriculture, most of the rural and tribal community is still practicing traditional agriculture. Mixed cropping, agroforestry, livestock-based farming and grazing-based agriculture performed in every part of the country. Although, shifting cultivation, alder based farming system in jhum cultivation and zabo system famous in Northeast India (Ramakrishan and Patnaik, 1992; Rathore et al., 2010; Singh et al., 2014). Whereas, aquaforestry, farming below the sea level, Kaipad and Pannendu practice in the south and coastal areas (Kumar and Ramakrishnan, 1990; Dagar et al., 1991; Sathyanathan, 2010; Vanaja, 2013; Bhushan et al., 2014).

The traditional practices are known for their novel importance in the environmental safeguarding from synthetic fertilizer contamination of agro-ecosystem. These also providing the livelihood and nutrition to the people along with strategies to mitigate the impact of climate change (Koohafkan and
Altieri, 2010). The agroforestry based agriculture are less prone threat as compared to modern and monocropping (Altieri and Nicholls, 2017). As the result of weighty ecological properties, maximum scientist's society acknowledges the traditional agriculture activities as the tool for to solve the various environmental threats, and economic crisis in future (Denevan 1995; Altieri, 2004). In this report, we discuss some of the agriculture practices which are used by the most part of the country to enhance the soil quality, microbial diversity, sustainability and environmental safeguarding of the society.

\section{Organic compost based-agriculture practice}

Organic composting is the process of microbiological degradation and recycling of waste into organic fertilizer (Singh and Singh, 2018). It is a non-polluting and environmentally safe method of waste management. These practices are very effectual in waste management generated after harvesting. It increases the soil organic matter on the degraded soil and reflect as a novel tool for restoration of polluted soil (Ren et al., 2017; Singh and Singh, 2018). It release nutrient element for biogeochemical cycling and humus for moisture maintenance in the cultivated system (Lim et al., 2016). Waste such as agriculture waste, garbage and crop residue used for biodegradation, have a different composition of $\mathrm{C} / \mathrm{N}$ ratios with available N, P, K (Masunga et al., 2016; Singh and Singh, 2017). The manure infusion in farming improves long-term fertility of soil with large productivity. Active compost has various types of microbial diversity such as bacteria (mesophilic or thermophilic), Actinobacteria, fungi, protozoans and rotifers. These participatory microbes release several kinds of hydrolytic enzyme and helpful in depolymerization and mineralization of waste (Kandeler et al., 1999; Marx et al., 2001). The 
demineralized nutrient elements are available for crop roots as nutrient and SOM content increase the moisture content and prevent the soil erosion. Organic matter of compost is important for traditional as well as modern agriculture to achieve sustainable agricultural production. it contains a desirable aspects in soil such as cation exchange capacity (CEC), high water holding capacity, sequestration of an organic and inorganic contaminant which collectively enhanced the physical, biological and chemical assets of soil (Padmavathiamma et al., 2008).

\section{Livestock-based agriculture practice}

Animal husbandry integrated agriculture is one of the oldest practices. This practice is considered the backbone of cultivation in tropical and developing country. These interactions create opportunities for diminishing extensive mechanization of the field and repair the recoupling of a different nutrient cycle of agro-system (Krall and Schuman, 1996; Hendrickson et al., 2008). About $50 \%$ of world meat production and $90 \%$ of peopleother requirements in developing country fulfilled by livestock (Thornton and Herrero, 2001). Crop-livestock system is the cyclic process in which animal produce milk and meat. Whereas, livestock's excreta used as FYM input for agriculture system and crop residue as a food requirement for livestock. Integrate livestock farming is loyal for maintenances of diversity in agriculture, field resources management and food security that help in improving the resilience of the agriculture system towards climate change (Singh and Singh, 2017). The FYM produced by the livestock is rich in soil nutrient, organic matter, soil microbial biomass, soil aeration and cation exchange capacity which diminishes degradation of soil with pest and disease management (Magdoff and Weil, 2004; Zhang et al., 2012; Liu et al., 2013; Singh and Singh, 2017).

\section{Agroforestry-based agriculture practice}

In agroforestry practice, crop species are cultivated in integration with tree species. The planted tree species may be fruit or fodder, depends upon the requirement of farmer. Agroforestry enhanced the biodiversity both above and below ground of the cultivated soil. The geographical coverage of agroforestry is $111,554 \mathrm{~km}^{2}$ in India, which is $3.39 \%$ of the total geographical area of India (FSI, 2013). The combination of tree, crops and animal husbandry in the agroforestry has great significance to soil conservation. It improves quality of soil, erosion reduction, soil moisture with promoted water holding capacity which likely develops the biodiversity of soil and carbon sequestration (Garrett and McGraw, 2000; Garrity, 2004; Williams-Guillen et al., 2008; Nair et al., 2009; Abbas et al., 2017). The incorporation of the plant that biologically fixes atmospheric nitrogen is most common in agroforestry. But non-nitrogen fixing plant also known forthe expeditionof the physical, chemical and biological feature of soil. It accumulating organic stock on the land surface by leaf litter and store soil carbon by sequestration and balanced the nutrient cycling in agrosystem (Jose, 2009). It is the special quality of agroforestry that develop agriculture sustainability, less dependent on the external chemical fertilizer and pesticides. Which reduce the adverse impact on soil system and environment (Moonen and Bàrberi, 2008; Radhakrishnan and Varadharajan 2016). In the silvopastoral system of agroforestry have special application of livestock, in which legume herbs/grasses planted with shrub or trees, make available the green fodder and ecological profits (Isaac et al., 2005; Reis et al., 2010). It also enhanced under soil $\mathrm{N}$ and $\mathrm{C}$ nutrient accumulation with healthy microbial diversity as compared to sole cultivation system (Arevalo et al., 1998; Montagnini et al., 2003; Tiessen et al., 2003). Several social 
and economic policy and profitability of farmer also received by agroforestry such as household earning, sustainability of crop system, soil conservation, adaptation and revenue from the local market (Mercer and Hyde, 1992; Alavalapati et al., 2001).

\section{Pasture cover or grazing based agriculture practices}

Pasture cover is one of the dominating type terrestrial land use practices in most part of the world and covers $40 \%$ of ice-free area of the earth (White et al., 2000). It provide a rich source of microbial and arthropods biodiversity. The tufts of the pasture provided a favorable temperature for microbial growth and the overall microbial diversity was found just double in these pasture cover microsite than bare microsite (Mathieu et al., 2009). Pasture were supply green feeding for grazers and deliver various ecosystem services such as carbon assimilation, water purification, recreational and aesthetic value in the form of ecotourism (Dignam et al., 2016). In many temperate nations of the world, legume plant cultivation with pasture is vital for the production of milk, fodder and meat. Because perennial legume is useful to for increase food quality, nitrogen enhancement by atmospheric microbial nitrogen fixation (Ledgard, 2001; Woodfield and Clark, 2009). The cattle of New Zealand dairy businesses are achieved about $90 \%$ of nutrient and fodder requirement from grazing of pasture (Bocquier and González-García, 2010). Pasture cover reduces the grazing pressure on forest and minimizes the degradation of the forest by reducing the grazing pressure of new one (seedling and sapling) of the tree. Pasture is considered as the serial in between the large forest and small spot of open forest, and farmyard manure of the animal dung is act as the nutrition for these forests. The dung of the animal with the combination of the dry leaf of plant and grass after decomposition act as the nutritive additive for soil. In Himalayan region of India, a dry leaf of forest and grasses of pasture are spread on the sheds of animal for making the warm in winter. At the end of the season, the bedding material of shed is decompose with mixed-up urine and dung of animal, farms farmyard manure for agriculture additive.

Traditional agriculture practices: integrating biophysical and social science for innovative system

Traditional agriculture is crucial to conserving the soil health and fulfill the requirement of high production demands by using the local resources and technique. These agriculture practices are holistic in nature because of its multidimensional importance in the agriculture fields, such as the health of environment, climate change and soil fertility (Pulido and Bocco, 2003). They improve the SOM with SOC by sequestration and biomass assimilation of crop residue into the field and mitigate the huge amount of GHGs (Aguilera et al., 2013; Sanz-Cobena et al., 2017). Agroforestry system of traditional agriculture expandthe mitigation activities of the system towards the climate change and produces 3-4 times more biomass as compare to tree-less cultivation with the large input of carbon as the nutrient (IPCC, 2000; Gattinger et al., 2012; Smith and Wollenberg, 2012; Tuomisto et al., 2012).

Traditional practices are the result of the several generation survival and often originated as the result of long spell observation of nature behavior (Martin et al., 2010). These practices provide new ideas for conniving climate smart-agriculture. Because these practices comprised of the preservation of natural resources with rational microbial diversity management. These practices encompassed intercropping, or mixed cropping with different varieties and cultivars, 
rotation of crops types, cover crops with composting and green manuring. The great scientist Darwin was also concluded that, the sustainability and stability of a system are fully dependent on the diversity of system. These practices have the ability to constitute a new model for future cultivation, but due to large production load of increasing population, these practices discarded (Malézieux, 2012). The new researchers need to invent in the area of sustainability of future agriculture and conservation of these natural systems of agriculture. They will develop a new innovative technique which is a hybrid of these systems as explained in figure 2 .
To develop these new techniques, firstly observe the functional activity of the species and also characterized the natural interaction between existing animals and vegetation species of the ecosystem. The local community has knowledge of the local natural system and scientist community needs to transform this traditional knowledge into new innovative and multidisciplinary knowledge system. It is a combination of agro-ecological knowledge of scientific community and traditional knowledge of the local community. This combination should be applied as new climate-smart approach for sustainable food production ensures global food security and environmental quality.

Fig.1 A simplified explanation of traditional agriculture application in soil microbial diversity

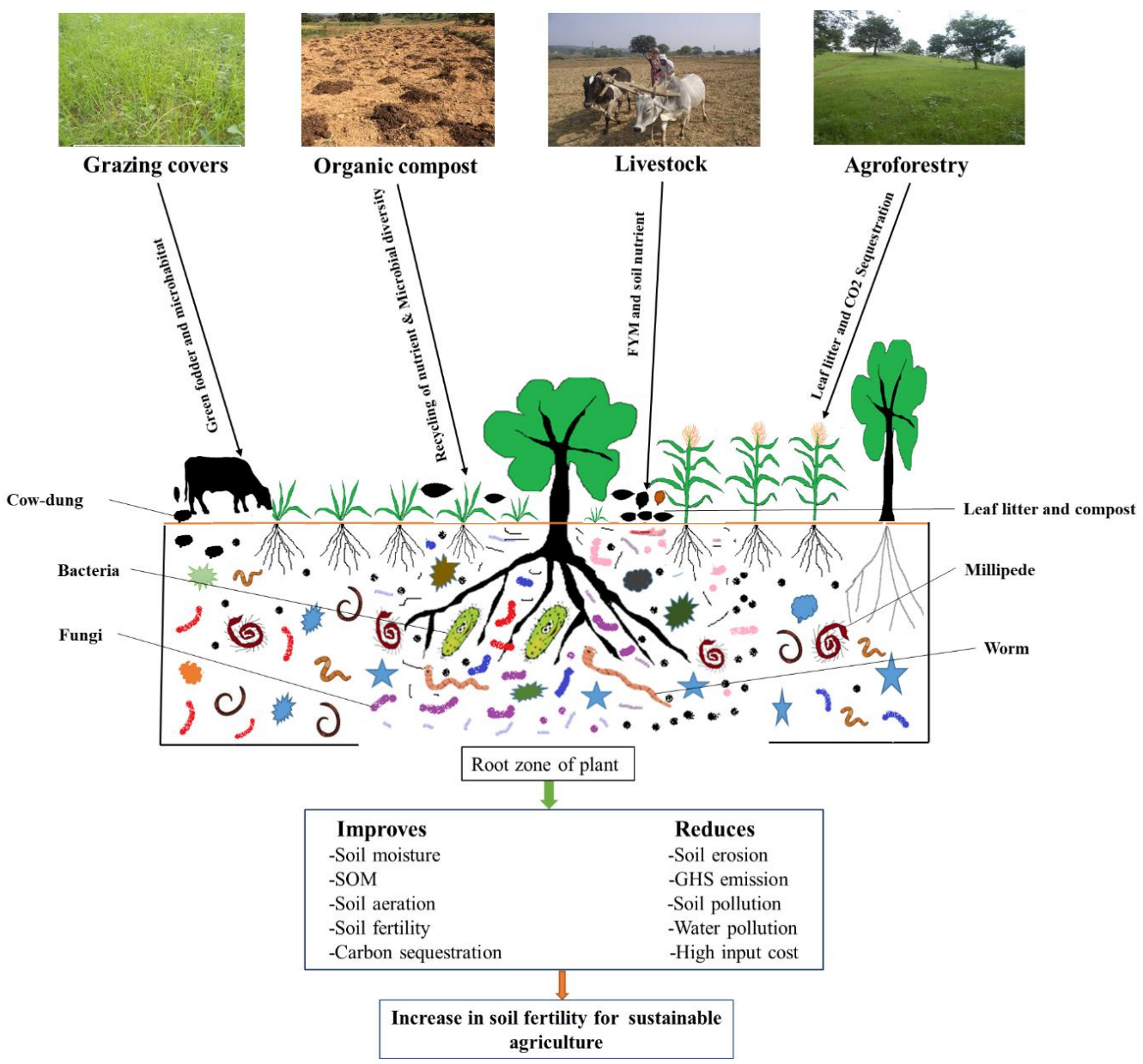


Fig.2 A diagrammatic framework for the mimic of traditional natural system

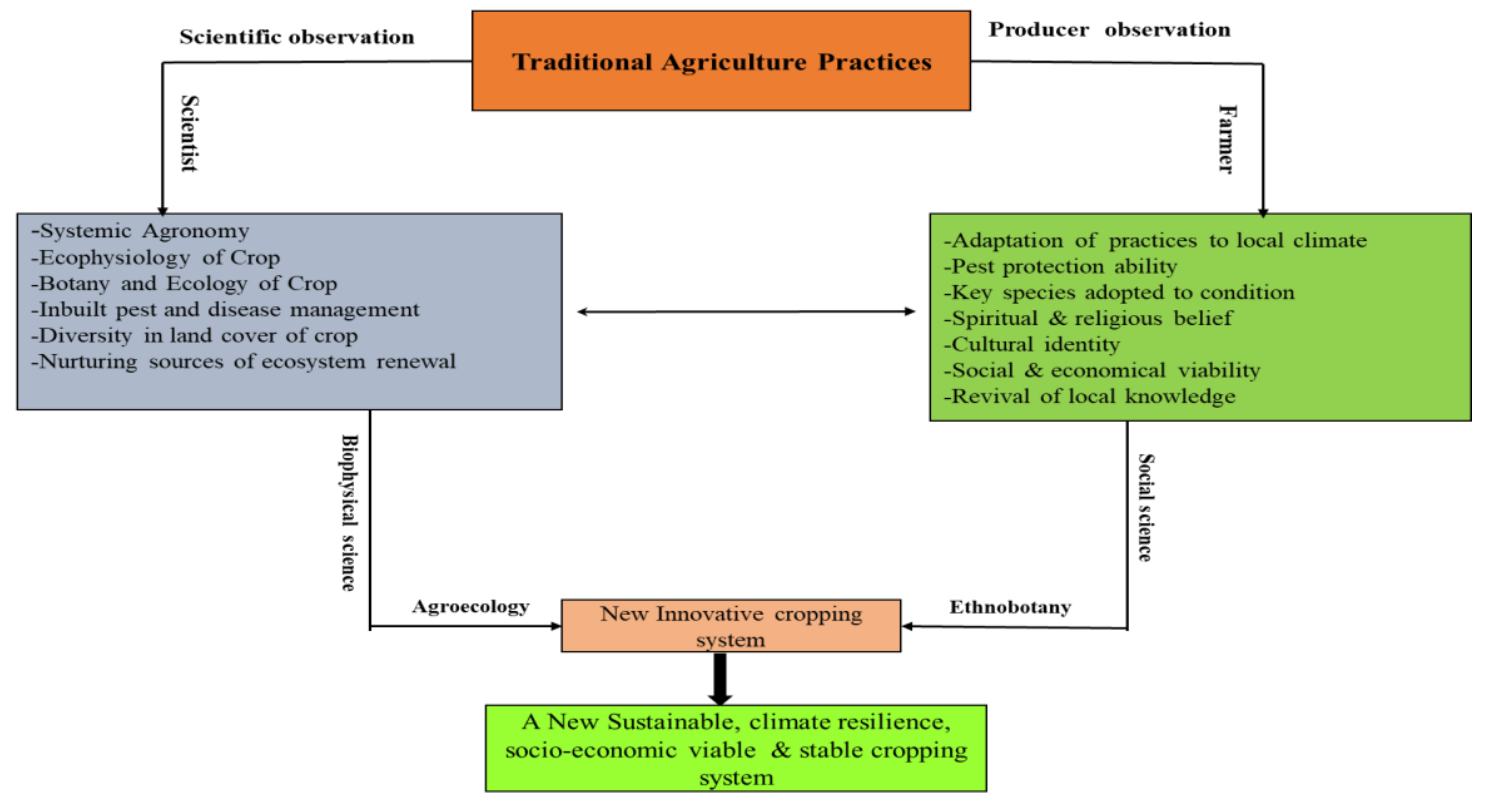

In conclusion traditional agriculture practices are very old agriculture practices. Agroforestry, livestock-based agriculture, mixed cropping, composting basedagriculture and grazing integrated practices are some of the prominent practices of the traditional agricultural system. These practices have capabilities to conserve belowground diversity of soil. Soil microbial diversity is an essential component of the soil health. Compost based farming rejuvenates the biogeochemical cycle of the nutrient element. Whereas, integration of livestock in farming decreases the mechanization of the field with availability of farm-yard manure (FYM) input. Agroforestry produces diversity on the field as well as below of the field, and enhance the soil organic carbon by carbon sequestration. The grazing field provides fodder for livestock with carbon assimilation and water purification by the root system. Traditional agriculture is also helpful in slashing of climate change, health safety of farmer, conservation of input energy and natural resources management. This is widely famous in the marginal farmers due to their low and locally existing input cost and great energy efficient output. Agroforestry, livestock-based agriculture, mixed cropping, composting based-agriculture and grazing integrated practices which are commonly practiced in India can be used as the model for the future sustainability of agriculture. Besides enhancing the soil microbial diversity, traditional agriculture practices are also having potential capability to adapt and mitigate the climate change. These practices would be an excellent alternative to the farmer toward environmental friendly and climate adaptive agro-ecosystem. There is an urgent need to explore traditional agriculture practices with a comprehensive and inclusive research for increasing food production in a healthy soil system characterized by biodiversity richness. This inclusion of traditional agricultural practices would be better alternative to modern agriculture in the current scenario of declining environmental health.

\section{Acknowledgements}

The authors are grateful to the Director and Head of Institute of Environment and Sustainable Development, BHU Varanasi for providing all necessary facilities. 


\section{References}

Abbas, F., Hammad, H. M., Fahad, S., Cerdà, A., Rizwan, M., Farhad, W., and Bakhat, H. F. (2017). Agroforestry: a sustainable environmental practice for carbon sequestration under the climate change scenarios - a review. Environmental Science and Pollution Research, 24(12), 11177-11191.

Abberton, M., Batley, J., Bentley, A., Bryant, J., Cai, H., Cockram, J., and Edwards, D. (2016). Global agricultural intensification during climate change: a role for genomics. Plant biotechnology journal, 14(4), 10951098.

Aguilera, E., Lassaletta, L., Gattinger, A., and Gimeno, B. S. (2013). Managing soil carbon for climate change mitigation and adaptation in Mediterranean cropping systems: a meta-analysis. Agriculture, Ecosystems and Environment, 168, 25-36.

Alavalapati, J., Nair, P. K. R., and Barkin, D. (2001). Socioeconomic and institutional perspectives of agroforestry. In World forests, markets and policies (pp. 71-83). Springer, Dordrecht.

Altieri, M. A. (2004). Linking ecologists and traditional farmers in the search for sustainable agriculture. Frontiers in Ecology and the Environment, 2(1), 35-42.

Altieri, M. A., and Nicholls, C. I. (2017). The adaptation and mitigation potential of traditional agriculture in a changing climate. Climatic Change, 140(1), 3345.

Anbalagan, V., Paulraj, M. G., Ignacimuthu, S., Baskar, K., and Gunasekaran, J. (2016). Natural enemy (ArthropodaInsecta) biodiversity in vegetable crops in Northeastern Tamil Nadu, India. International Letters of Natural
Sciences, 53.

Arevalo, L. A., Alegre, J. C., Bandy, D. E., and Szott, L. T. (1998). The effect of cattle grazing on soil physical and chemical properties in a silvopastoral system in the Peruvian Amazon. Agroforestry Systems, 40(2), 109-124.

Balota, E. L., Colozzi Filho, A., Andrade, D. S., and Dick, R. P. (2004). Long-term tillage and crop rotation effects on microbial biomass and $\mathrm{C}$ and $\mathrm{N}$ mineralization in a Brazilian Oxisol. Soil and Tillage Research, 77(2), 137145.

Berkes, F., Colding, J., and Folke, C. (2000). Rediscovery of traditional ecological knowledge as adaptive management. Ecological applications, 10(5), 12511262.

Bhalla, G. S., and Singh, G. (2009). Economic liberalisation and Indian agriculture: a statewise analysis. Economic and Political Weekly, 3444.

Bhushan, C. (2014). Rising to the call: good practices of climate change adaptation in India. Centre for Science and Environment.

Bitew, Y., and Alemayehu, M. (2017). Impact of crop production inputs on soil health: A review. Asian Journal of Plant Sciences, 16, 109-131.

Bocquier, F., and González-García, E. (2010). Sustainability of ruminant agriculture in the new context: feeding strategies and features of animal adaptability into the necessary holistic approach. Animal, 4(7), 1258-1273.

Buckley, D. H., and Schmidt, T. M. (2003). Diversity and dynamics of microbial communities in soils from agro-ecosystems. Environmental Microbiology, 5(6), 441-452.

Camenzind, T., Hättenschwiler, S., Treseder, K. K., Lehmann, A., and Rillig, M. C. (2018). Nutrient limitation of soil 
microbial processes in tropical forests. Ecological Monographs, 88(1), 4-21.

Chenu, C., Angers, D. A., Barré, P., Derrien, D., Arrouays, D., and Balesdent, J. (2018). Increasing organic stocks in agricultural soils: Knowledge gaps and potential innovations. Soil and Tillage Research.

Chhetry, G. K. N., and Belbahri, L. (2009). Indigenous pest and disease management practices in traditional farming systems in north east India. A review. Journal of plant breeding and crop science, 1(3), 028-038.

Chivenge, P. P., Murwira, H. K., Giller, K. E., Mapfumo, P., and Six, J. (2007). Long-term impact of reduced tillage and residue management on soil carbon stabilization: Implications for conservation agriculture on contrasting soils. Soil and Tillage Research, 94(2), 328-337.

Dagar, J. C., Mongia, A. D., and Bandyopadhyay, A. K. (1991). Mangroves of Andaman and Nicobar Islands. Oxford and IBH Pub. Co..

Denevan, W. M. (1995). 2 Prehistoric agricultural methods as models for sustainability. In Advances in Plant Pathology (Vol. 11, pp. 21-43). Academic Press.

Dignam, B. E., M. O'Callaghan, L. M. Condron, J. M. Raaijmakers, G. A. Kowalchuk, and S. A. Wakelin. (2016). Challenges and opportunities in harnessing soil disease suppressiveness for sustainable pasture production. Soil Biology and Biochemistry 95: 100-111.

Dogliotti, S., García, M. C., Peluffo, S., Dieste, J. P., Pedemonte, A. J., Bacigalupe, G. F., and Rossing, W. A. H. (2014). Co-innovation of family farm systems: A systems approach to sustainable agriculture. Agricultural Systems, 126, 76-86.
FAO, (2011). Save and Grow: A Policymaker's Guide to Sustainable Intensification of Smallholder Crop Production. FAO, Rome, Italy, 102.

Friedrich, T., Kassam, A. H., and Shaxson, F. (2009). Conservation agriculture. Agriculture for Developing Countries, 6, 3-9. Science and Technology Options Assessment (STOA) project. European Technology Assessment Group, Karlsruhe, Germany.

FSI (2013). State of Forest Report. Forest Survey of India, Dehradun, Ministry of Environment and Forests, Government of India.

Garrett, H. E., McGraw, R. L., and Walter, W. D. (2009). Alley cropping practices. North American Agroforestry: An Integrated Science and Practice 2nd edition, (northamericanag), 133-162.

Garrity, D. P. (2004). Agroforestry and the achievement of the Millennium Development Goals. Agroforestry systems 61(1-3): 5-17.

Gattinger, A., Muller, A., Haeni, M., Skinner, C., Fliessbach, A., Buchmann, N., and Niggli, U. (2012). Enhanced top soil carbon stocks under organic farming. Proceedings of the National Academy of Sciences, 109(44), 18226-18231.

Glick, B. R. (1995). The enhancement of plant growth by free-living bacteria. Canadian journal of microbiology, 41(2), 109-117.

Haas, D., and Défago, G. (2005). Biological control of soil-borne pathogens by fluorescent pseudomonads. Nature reviews microbiology, 3(4), 307-319.

Hendrickson, J. R., Hanson, J. D., Tanaka, D. L., and Sassenrath, G. (2008). Principles of integrated agricultural systems: Introduction to processes and definition. Renewable Agriculture and Food Systems, 23(4), 265-271.

IFAD, (2012). Sustainable smallholder 
agriculture: Feeding the world, protecting the planet. IFAD, Rome, Italy, 45.

IPCC (2000). Land Use, Land Use Change and Forestry. UNEP: WMO; (2000).

Isaac, M. E., Gordon, A. M., Thevathasan, N., Oppong, S. K., and Quashie-Sam, J. (2005). Temporal changes in soil carbon and nitrogen in West African multistrata agroforestry systems: a chronosequence of pools and fluxes. Agroforestry Systems, 65(1), 23-31.

Jose, S. (2009). Agroforestry for ecosystem services and environmental benefits: an overview. Agroforestry systems 76(1): $1-10$.

Kandeler, E., Stemmer, M., Palli, S., and Gerzabek, M. H. (1999). Xylanase, invertase and urease activity in particle-size fractions of soils. In Effect of Mineral-OrganicMicroorganism Interactions on Soil and Freshwater Environments (pp. 275-286). Springer, Boston, MA.

Kaurin, A., Mihelič, R., Kastelec, D., Grčman, H., Bru, D., Philippot, L., and Suhadolc, M. (2018). Resilience of bacteria, archaea, fungi and $\mathrm{N}$ cycling microbial guilds under plough and conservation tillage, to agricultural drought. Soil Biology and Biochemistry, 120, 233-245.

Koohafkan, P., and Altieri, M. A. (2011). Globally important agricultural heritage systems: a legacy for the future. Rome: Food and Agriculture Organization of the United Nations.

Krall, J. M., and Schuman, G. E. (1996). Integrated dryland crop and livestock production systems on the Great Plains: Extent and outlook. Journal of Production Agriculture, 9(2), 187191.

Kumar, A., and P. S. Ramakrishnan. (1990). Energy flow through an Apatani village ecosystem of Arunachal
Pradesh in northeast India. Human Ecology, 18(3), 315-336.

Kumar, A., Maurya, B. R., Raghuwanshi, R., Meena, V. S., and Islam, M. T. (2017). Co-inoculation with Enterobacter and Rhizobacteria on yield and nutrient uptake by wheat (Triticum aestivum L.) in the alluvial soil under indogangetic plain of India. Journal of plant growth Regulation, 36(3), 608617.

Lal, R. (2009). Challenges and opportunities in soil organic matter research. European Journal of Soil Science 60(2): 158-169.

Ledgard, S. F. (2001). Nitrogen cycling in low input legume-based agriculture, with emphasis on legume/grass pastures. Plant and Soil 228(1): 43-59.

Lim, S. L., Lee, L. H., and Wu, T. Y. (2016). Sustainability of using composting and vermicomposting technologies for organic solid waste biotransformation: recent overview, greenhouse gases emissions and economic analysis. Journal of Cleaner Production, 111, 262-278.

Liu, Y., Duan, M., and Yu, Z. (2013). Agricultural landscapes and biodiversity in China. Agriculture, ecosystems and environment, 166, 4654.

Lucy, M., Reed, E., and Glick, B. R. (2004). Applications of free living plant growth-promoting rhizobacteria. Antonie van leeuwenhoek, 86(1), 1-25.

Magdoff F, Weil R. (2004). Soil organic matter management strategies. In: Magdoff F, Weil R (eds) Soil organic matter in sustainable agriculture. CRC Press, Boca Raton.

Malézieux, E. (2012). Designing cropping systems from nature. Agron. Sustain. Dev. 32:15-29. DOI 10.1007/s13593011-0027-z.

Martin, J. F., Roy, E. D., Diemont, S. A., and 
Ferguson, B. G. (2010). Traditional Ecological Knowledge (TEK): Ideas, inspiration, and designs for ecological engineering. Ecological Engineering, 36(7), 839-849.

Marx, M. C., Wood, M., and Jarvis, S. C. (2001). A microplate fluorimetric assay for the study of enzyme diversity in soils. Soil biology and biochemistry, 33(12-13), 1633-1640.

Masunga, R. H., Uzokwe, V. N., Mlay, P. D., Odeh, I., Singh, A., Buchan, D., and De Neve, S. (2016). Nitrogen mineralization dynamics of different valuable organic amendments commonly used in agriculture. Applied Soil Ecology, 101, 185-193.

Mathieu, J., Grimaldi, M., Jouquet, P., Rouland, C., Lavelle, P., Desjardins, T., and Rossi, J. P. (2009). Spatial patterns of grasses influence soil macrofauna biodiversity in Amazonian pastures. Soil Biology and Biochemistry, 41(3), 586-593.

Menezes-Blackburn, D., Paredes, C., Zhang, H., Giles, C. D., Darch, T., Stutter, M., and Wendler, R. (2016). Organic acids regulation of chemical-microbial phosphorus transformations in soils. Environmental science and technology, 50(21), 11521-11531.

Mercer, D. E., and Hyde W. F. (1992). The economics of agroforestry. Social Science Applications in Asian Agroforestry. Winrock International, USA and South Asia Books, Arlington, VA, 111-143.

Mohan, R. (2006). Agricultural credit in India: status, issues and future agenda. Econ. Pol. Wkly. 41, 1013-1023.

Montagnini, F., Ugalde, L., and Navarro, C. (2003). Growth characteristics of some native tree species used in silvopastoral systems in the humid lowlands of Costa Rica. Agroforestry systems, 59(2), 163-170.
Moonen, A. C., and Barberi, P. (2008). Functional biodiversity: an agroecosystem approach. Agriculture, ecosystems and environment, 127(12), 7-21.

Morelli, F. (2018). High nature value farmland increases taxonomic diversity, functional richness and evolutionary uniqueness of bird communities. Ecological Indicators, 90, 540-546.

Murthy, I. K., Gupta, M., Tomar, S., Munsi, M., Tiwari, R., Hegde, G. T., and Ravindranath, N. H. (2013). Carbon sequestration potential of agroforestry systems in India. J Earth Sci Climate Change, 4(1), 1-7.

Nair P. K. R., Kumar B. M. and Nair V. D. (2009). Agroforestry as a strategy for carbon sequestration. Journal of Plant Nutrition and Soil Science 172:10-23.

Padmavathiamma, P. K., Li, L. Y., and Kumari, U. R. (2008). An experimental study of vermi-biowaste composting for agricultural soil improvement. Bioresource Technology, 99(6), 1672-1681.

Paz-Ferreiro, J., and Fu, S. (2016). Biological indices for soil quality evaluation: perspectives and limitations. Land Degradation and Development, 27(1), 14-25.

Plieninger, T., Höchtl, F., and Spek, T. (2006). Traditional land-use and nature conservation in European rural landscapes. Environmental science and policy, 9(4), 317-321.

Pulido, J. S., and Bocco. G. (2003). The traditional farming system of a Mexican indigenous community: The case of Nuevo San Juan Parangaricutiro, Michoacán, Mexico. Geoderma, 111(3-4): 249-265.

Radhakrishnan, S., and Varadharajan, M. (2016). Status of microbial diversity in agroforestry systems in Tamil Nadu, 
India. Journal of basic microbiology, 56(6), 662-669.

Ram, A., Dev, I., Uthappa, A. R., Kumar, D., Kumar, N., Chaturvedi, O. P., and Meena, B. P. (2017). Reactive Nitrogen in Agroforestry Systems of India. The Indian Nitrogen Assessment: Sources of Reactive Nitrogen, Environmental and Climate Effects, Management Options, and Policies, 207.

Ramakrishnan, P. S., and Patnaik. S. (1992). Jhum: slash and burn cultivation. India International Centre Quarterly 19(1/2): 215-220.

Rao, C. S., Kareemulla, K., Krishnan, P., Murthy, G. R. K., Ramesh, P., Ananthan, P. S., and Joshi, P. K. (2018). Agro-ecosystem based sustainability indicators for climate resilient agriculture in India: A conceptual framework. Ecological Indicators.

Rasmann, S., Bennett, A., Biere, A., Karley, A., and Guerrieri, E. (2017). Root symbionts: Powerful drivers of plant above-and belowground indirect defenses. Insect science, 24(6), 947960.

Rathore, S. S., Karunakaran, K. and Prakash, B. (2010). Alder based farming system a traditional farming practices in Nagaland for amelioration of jhum land. Indian Journal of TraditionalKnowledge 9(4): 677-680.

Reis, G. L., Lana, Â. M. Q., Maurício, R. M., Lana, R. M. Q., Machado, R. M., Borges, I., and Neto, T. Q. (2010). Influence of trees on soil nutrient pools in a silvopastoral system in the Brazilian Savannah. Plant and soil, 329(1-2), 185-193.

Ren, X., Zeng, G., Tang, L., Wang, J., Wan, J., Wang, J., and Peng, B. (2017). The potential impact on the biodegradation of organic pollutants from composting technology for soil remediation. Waste Management.

Sanz-Cobena, A., Lassaletta, L., Aguilera, E., Del Prado, A., Garnier, J., Billen, G., Iglesias, A., Sanchez, B., Guardia, G., Abalos, D., and Plaza-Bonilla, D. (2017). Strategies for greenhouse gas emissions mitigation in Mediterranean agriculture: A review. Agriculture, Ecosystems \&Environment 238: 5-24.

Sathyanathan, N. (2010). Overview of farming practices in the water-logged areas of Kerala, India. International Journal of Agricultural and Biological Engineering 3(4): 28-43.

Schloter, M., Nannipieri, P., Sørensen, S. J., and van Elsas, J. D. (2018). Microbial indicators for soil quality. Biology and Fertility of Soils, 54(1), 1-10.

Singh, A. K., A. Arunachalam, S. V. Ngachan, K. P. Mohapatra, and J. C. Dagar. (2014). From shifting cultivation to integrating farming: Experience of agroforestry development in the northeastern Himalayan region. In Agroforestry Systems in India: Livelihood Security \&Ecosystem Services (pp. 57-86). Springer, New Delhi.

Singh, A., and Singh, G. S. (2017). Vermicomposting: A sustainable tool for environmental equilibria. Environmental Quality Management, 27(1), 23-40.

Singh, A., and Singh, G. S. (2018). Is earthworm a protagonist or an antagonist in greenhouse gas (GHG) emissions from the soil? International Journal of Environmental Science and Technology, 1-14.

Singh, R., and Singh, G.S. (2017). Traditional agriculture: a climate-smart approach for sustainable food production. Energy, Ecology and Environment 2(5): 296-316.

Sinha, R. K. (1997). Embarking on the second 
green revolution for sustainable agriculture in India: a judicious mix of traditional wisdom and modern knowledge in ecological farming. Journal of Agricultural and Environmental Ethics 10(2):183-197.

Smith, P., and Wollenberg, E. (2012). Achieving mitigation through synergies with adaptation. Climate Change Mitigation and Agriculture 50-57.

Söderström, B., Hedlund, K., Jackson, L. E., Kätterer, T., Lugato, E., Thomsen, I. K., and Jørgensen, H. B. (2014). What are the effects of agricultural management on soil organic carbon (SOC) stocks?. Environmental Evidence, 3(1), 2.

Srivastava, P., Singh, R., Tripathi, S., and Raghubanshi, A. S. (2016). An urgent need for sustainable thinking in agriculture-An Indian scenario. Ecological indicators, 67, 611-622.

Thornton, P. K., and Herrero, M. (2001). Integrated crop-livestock simulation models for scenario analysis and impact assessment. Agricultural Systems 70(2-3): 581-602.

Tiessen, H., Menezes, R. S. C., Salcedo, I. H., and Wick, B. (2003). Organic matter transformations and soil fertility in a treed pasture in semiarid NE Brazil. Plant and Soil, 252(2), 195-205.

Tuomisto, H. L., Hodge, I.D., Riordan, P. and Macdonald, D.W. (2012). Does organic farming reduce environmental impacts?-A meta-analysis of European research. Journal of Environmental Management 112: 309 320.
Vanaja, T. (2013). KAIPAD-a unique, naturally organic, saline prone rice ecosystem of Kerala, India. American Journal of Environmental Protection 2(2): 42-46.

Wezel, A., Bellon, S.,Doré, T., Francis, C., Vallod, D., and David, C. (2011). Agroecology as a science, a movement and a practice. In Sustainable Agriculture, 2, 27-43. Springer, Dordrecht.

White, R. P., Murray, S., Rohweder, M., Prince, S. D., and Thompson, K. M. (2000). Grassland ecosystems (p. 81). Washington, DC, USA: World Resources Institute.

Williams-Guillén, K., Perfecto, I., and Vandermeer J. (2008). Bats limit insects in a neotropical agroforestry system. Science 320(5872): 70-70.

Woodfield, D. R., and Clark, D. A. (2009). Do forage legumes have a role in modern dairy farming systems?.Irish Journal of Agricultural and Food Research 137-147.

Yadav, S. K., Babu, S., Yadav, M. K., Singh, K., Yadav, G. S., and Pal, S. (2013). A review of organic farming for sustainable agriculture in Northern India. International Journal of Agronomy.

Zhang, Q. C., Shamsi, I. H., Xu, D. T., Wang, G. H., Lin, X. Y., Jilani, G., and Chaudhry, A. N. (2012). Chemical fertilizer and organic manure inputs in soil exhibit a vice versa pattern of microbial community structure. Applied Soil Ecology, 57, 1-8.

\section{How to cite this article:}

Sanoj Kumar Patel, Archana Singh, and Gopal Shankar Singh. 2019. Food Production Through Traditional Agriculture: an Urgent Need to Improve Soil Health by Sustaining Soil Microbial Diversity. Int.J.Curr.Microbiol.App.Sci. 8(01): 183-196. doi: https://doi.org/10.20546/ijcmas.2019.801.020 